\title{
Investigation of damaged layer formed at mechanical treatment of sapphire using three-crystal X-ray diffraction method
}

\author{
V.F.Tkachenko, S.I.Kryvonogov, A.T.Budnikov, \\ O.A.Lukienko, E.A.Vovk
}

Institute for Single Crystals, STC "Institute for Single Crystals", National Academy of Sciences of Ukraine, 60 Lenin Ave., 61001 Kharkiv, Ukraine

Received March 30, 2014

\begin{abstract}
The methods of three-crystal X-ray diffractometry were used for investigating structure perfection in surface-adjacent damaged layer (DL) formed in the process of mechanical and chemical-mechanical treatment of sapphire crystals with the surface orientation $\langle 0001\rangle,\langle 11 \overline{2} 0\rangle$. Analysis of the diffraction reflection curves made it possible to establish the structure and character of distortions in the DL. There was established the meansquare disorientation between the fragments, which allowed to characterize the defects structure of the surface-adjacent DL.
\end{abstract}

\footnotetext{
Методами прецизионной трехкристальной рентгеновской дифрактометрии исследованы совершенства структуры в приповерхностном нарушенном слое (НС), образовавшемся во время механической и химико-механической обработки сапфира с ориентацией поверхности $\langle 0001\rangle,\langle 11 \overline{2} 0\rangle$. Анализ кривых дифракционного отражения позволил установить структуру и характер искажений в НС. Определена среднеквадратичная разориентация между фрагментами, что позволило охарактеризовать дефектность структуры приповерхностного НС.
}

Використання методів трикристальної рентгенівської дифрактометрії при дослідженні порушеного шару, що утворився внаслідок механічної обробки сапфіру. В.Ф.Ткаченко, С.І.Кривоногов, О.Т.Будніков, О.О.Лукієнко, О.О.Вовк.

Методами прецизійної трикристальної рентгенівської дифрактометрії досліджено досконалості структури у приповерхневому порушеному шарі (ПШ), що утворився під час механічної та хіміко-механічної обробки сапфіру з орієнтацією поверхні 0001$\rangle$, $\langle 11 \overline{2} 0\rangle$. Аналіз кривих дифракційного відбиття дозволив встановити структуру та характер спотворень в ПШ. Встановлено середньоквадратичну разорієнтацію між фрагментами, що дозволило охарактеризувати дефектність структури приповерхневого ПШ.

\section{Introduction}

The problem of damaged layer (DL) in sapphire crystals has considerable practical significance while solving various technological tasks [1]. Such a layer is formed on the surface at all the stages of mechanical treatment of the crystal: cutting, grinding, mechanical polishing.

Up to now a unified model of the structure of DL has not been developed. How- ever, the model reported in [2] is considered to be most realistic. In its frames the damaged layer consists of three successive zones: distorted amorphous or polycrystalline layer, distorted cracked layer with considerable disorientation of single-crystalline fragments, and the crystal matrix with elevated vacancy density of vacancies and dislocations. As reported in [3], besides the matrix there is observed a zone with a 
depth up to 1.5-2 $\mu \mathrm{m}$ containing crystallites with block disorientation angles of several degrees. According to different authors, the depth of the layer damaged by treatment reaches 50-70 $\mu \mathrm{m}$. The structure of each zone is defined by the character of the action of cutting tool on the crystal, the treatment conditions, the abrasive grain size. The processes of deformation in the DL are essentially influenced by lubricating and cooling liquors used at treatment [4]. Various ideas of the structure of the damaged surface-adjacent layer may be connected with different investigation methods which imply fixation of either all the zones or only some of them [5-7].

In this connection, precision methods of three-crystal X-ray diffractometry (TCD) are informative enough [8]. They have been used for characterization of the structure perfection of sapphire single crystals grown under reducing conditions [9-13].

The aim of the present work was to investigate the structure of the damaged surface-adjacent layer formed in the process of mechanical treatment of sapphire single crystals, using the methods of TCD.

\section{Results and discussion}

The study was performed on $200 \times 200 \times 35 \mathrm{~mm}^{3}$ crystals grown by the method of horizontally oriented crystallization in reducing gaseous medium [14, 15].

The rectangular part of an ingot of sapphire crystal with the orientation $\langle 0001\rangle$ was used to cut out ingots with the dimensions $40 \times 40 \times 35 \mathrm{~mm}^{3}$ and the orientation of the faces $\langle 0001\rangle,\langle 11 \overline{2} 0\rangle$ and $\langle 10 \overline{1} 0\rangle$, the orientation accuracy being $\leq 0.5^{\circ}$. From these ingots there were obtained plates of the orientation $\langle 0001\rangle$ and $\langle 11 \overline{2} 0\rangle$ with a thickness of 0.4 and $0.7 \mathrm{~mm}$. For cutting we applied a diamond wheel with attached abrasive of a graininess of 125/100 using lubricating and cooling liquor. One side of these plates was subjected to mechanical polishing (MP) by means of a diamond abrasive ACM 28/20 followed by chemical-mechanical polishing (CMP) in silicon dioxide suspension to completely remove the damaged surface-adjacent layer [12-14]. The other side of the plates meant for X-ray investigations underwent one of the following kinds of treatment: cutting by means of diamond disk, MP using ACM 28/20 abrasive, or CMP. X-ray diffraction study was carried out on a three-crystal X-ray diffrac- tometer in $\mathrm{Cu} \mathrm{K}_{\alpha 1}$-radiation [16]. Diffraction reflection curves (DRC) were recorded in the Bragg geometry for symmetric and asymmetric reflections, different values of the Bragg angle $\Theta$ (Table) and the angle of incidence of the primary beam on the investigated sample $\alpha$ at asymmetric survey. This allowed to obtain information concerning the structure perfection of the DL at different depth. At the angle $\Theta$ ranging from 18.89 to 62.19 ang. deg. the depth of X-ray penetration changes by 13.6 times. This value can be essentially varied depending on the radiation wavelength $\lambda$. For $\mathrm{Cr} \mathrm{K}_{\alpha}$ the linear coefficient of absorption $\mu$ for $\mathrm{Al}_{2} \mathrm{O}_{3}$ is $388.97 \mathrm{~cm}^{-1}$, for $\mathrm{Cu} \mathrm{K}_{\alpha} \mu=126.0 \mathrm{~cm}^{-1}$, for Mo $\mathrm{K}_{\alpha} \mu=13.97 \mathrm{~cm}^{-1}$, i.e. for the given radiations $\mu$ changes by 27.8 times. Presented in Table is the depth of penetration of monochromatic ray estimated on the assumption that it is equal to $1 / 2 \mu$, taking into account the reflection angle $\Theta$ for symmetric reflections and the angle $\alpha$ at asymmetric survey.

When using a $4 \mathrm{~mm}$ vertical slot located behind the second monochromator the height of X-ray beam incident on the studied sample is $14 \mathrm{~mm}$. For the beam with a width of $0.05 \mathrm{~mm}$ it is easy to calculate the area of the irradiated sample surface $S$ taking into account the angle $\Theta$ (Table). Since the total intensity of all the peaks is proportional to the area $S$, the area of a fragment of DRC peak is determined from the quantity of fragmented DRC peaks for the reflections $\langle 40 \overline{4} 8\rangle$ and $\langle 30 \overline{3} 0\rangle$ (Fig. 1-3) and the intensity $I_{\text {max }}$ of the considered peak. Assuming that a fragment of a crystallite on the sample surface is of round shape with the area $S=\pi D^{2} / 4$ one can determine the crystallite diameter (Fig. 4). The irradiated sample surface contains disoriented crystallites which produce reflections at angles $\Theta_{i}$ lesser or larger than $\Theta_{B}$. Therefore, one can determine the meansquare turn of the crystallites $\sigma$ as

$$
\sigma=\sqrt{\frac{\left(\Theta_{B}-\Theta_{i}\right)^{2}}{n-1},}
$$

where $n$ is the quantity of the crystallites.

From DRC (Fig. 1) it is easy to measure the maximum angle between two crystallites located on the irradiated surface $\Delta \Theta_{\max }$. The characteristics halfwidth of the DRC $\beta$, the width $\beta^{\prime}$ measured at $10 \%$ height of the DRC maximum, integral reflection power $R_{B}$, 
Table 1. Parameters characterizing structure perfection of investigated samples

\begin{tabular}{|c|c|c|c|c|c|c|c|c|c|c|c|c|c|c|}
\hline \multirow[t]{2}{*}{ Reflection } & \multirow[t]{2}{*}{$\begin{array}{l}\Theta \\
\mathrm{deg}\end{array}$} & \multirow[t]{2}{*}{$\begin{array}{c}S \cdot 10^{-6} \\
\mu \mathrm{m}^{2}\end{array}$} & \multirow[t]{2}{*}{$d, \mu \mathrm{m}$} & \multicolumn{5}{|c|}{$\begin{array}{l}\text { Cutting using diamond disk } \\
\text { with a graininess of } 125 / 100\end{array}$} & \multicolumn{3}{|c|}{$\begin{array}{l}\text { Mechanical } \\
\text { treatment using } \\
\text { ACM 28/20 }\end{array}$} & \multicolumn{3}{|c|}{$\begin{array}{c}\text { Chemical- } \\
\text { mechanical } \\
\text { polishing with } \mathrm{SiO}_{2}\end{array}$} \\
\hline & & & & $\begin{array}{c}\beta \\
\text { sec }\end{array}$ & $\begin{array}{l}\beta^{\prime} \\
\text { sec }\end{array}$ & $R \cdot 10^{6}$ & $\begin{array}{c}\sigma \\
\sec \end{array}$ & $\begin{array}{l}\Delta \Theta \\
\text { sec }\end{array}$ & $\begin{array}{l}\beta, \\
\text { sec }\end{array}$ & $\begin{array}{l}\beta^{\prime}, \\
\text { sec }\end{array}$ & $R \cdot 10^{6}$ & $\begin{array}{c}\beta, \\
\text { sec }\end{array}$ & $\begin{array}{l}\beta^{\prime}, \\
\text { sec }\end{array}$ & $R \cdot 10^{6}$ \\
\hline$\langle 0006\rangle$ & 20.84 & 1.96 & 14.12 & 59.1 & 252 & 7.14 & 91.2 & 550.3 & 14.1 & 59.2 & 5.4 & 6.7 & 25.2 & 4.82 \\
\hline$\langle 00012\rangle$ & 45.33 & 0.98 & 28.24 & 54.3 & 108.2 & 33.25 & 85.4 & 318.8 & 12.6 & 52.9 & 22.5 & 6.5 & 24.1 & 13.1 \\
\hline$\langle 11 \overline{2} 0\rangle$ & 18.89 & 2.16 & 12.85 & 61.7 & 321 & 33.6 & 126.6 & 504 & 13.9 & 58.4 & 37.9 & 7.6 & 30.4 & 29.6 \\
\hline$\langle 22 \overline{4} 0\rangle$ & 40.36 & 1.08 & 25.70 & 30.9 & 141.4 & 32.4 & 85.9 & 312 & 23.4 & 96.0 & 19.2 & 6.7 & 26.2 & 12.4 \\
\hline$\langle 33 \overline{6} 0\rangle$ & 76.25 & 0.71 & 38.54 & 32.1 & 138.8 & 14.2 & 84.2 & 280 & 26.8 & 182 & 39.4 & 18.8 & 76 & 36.2 \\
\hline $\begin{array}{l}\langle 40 \overline{4} 8\rangle \\
\text { surface } \\
\langle 0001\rangle \\
\alpha=4.7^{\circ}\end{array}$ & 62.19 & 8.48 & 3.25 & 249 & 501 & 35.1 & 204 & 682 & 24.8 & 104 & 32.8 & 11.2 & 46.2 & 12.87 \\
\hline $\begin{array}{l}\langle 30 \overline{3} 0\rangle \\
\text { surface } \\
\langle 11 \overline{2} 0\rangle \\
\alpha=4.1^{\circ}\end{array}$ & 34.1 & 9.79 & 2.84 & 267.4 & 494 & 22.2 & 175 & 784 & 25.4 & 102.2 & 78.6 & 8.2 & 33.4 & 32.2 \\
\hline
\end{tabular}

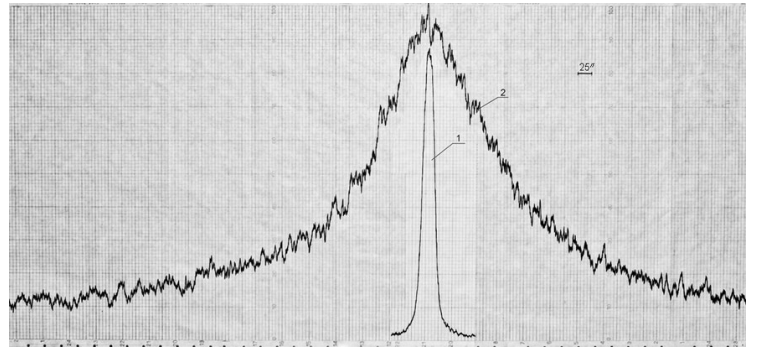

Fig. 1. DRC recorded in the Bragg geometry using TCD for the asymmetric reflection $\langle 40 \overline{4} 8\rangle$, the crystallographic orientation of the surface $\langle 0001\rangle: 1$ - without damaged layer (the scale 1000 pulses/sec), 2 - with damaged layer (the scale 100 pulses/sec).

mean-square turn of the crystallites $\sigma$, angle between the fragments $\Delta \Theta_{\max }$ and the distribution of the crystallite sizes (Table, Fig. 4) describe the DL completely enough.

The use of X-radiation with different values of $\lambda$, the diffraction angle $\Theta$ for different reflections and survey geometry makes it possible to obtain information concerning structure distortions in the depth of the surface-adjacent layer. Step-by-step removal of the DL using CMP [14, 15] allows to determine its thickness $h$ from the dependences $\beta(h)$ and $R_{B}(h)$.

For the samples of a chosen thickness examined in the Laue geometry with registration of reflected and anomalously transmitted X-rays, $\left(R_{i}\right)$ and $\left(T_{i}\right)$, respectively, there

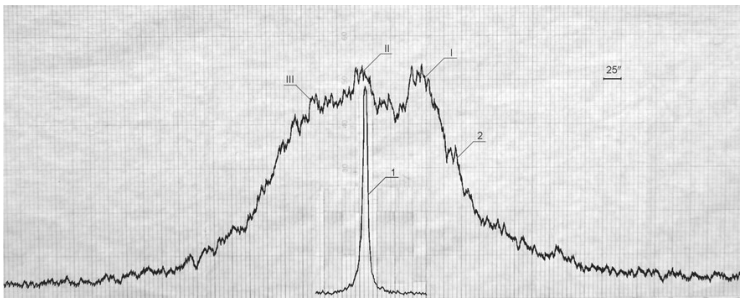

Fig. 2. DRC recorded using TCD in the Laue geometry, the reflection $\langle 30 \overline{3} 0\rangle$, the crystallographic orientation of the surface $\langle 11 \overline{2} 0\rangle$ : 1 - in the absence of the damaged surfaceadjacent layer (the scale 1000 pulses/sec), 2 - in the presence of the damaged surfaceadjacent layer (the scale 200 pulses/sec).

is fulfilled the condition of dynamic reflection in the approximation of "thick crystal" (500-1500 $\mu \mathrm{m})$, where $R_{i}=T_{i}$ [8,9]. The DRC measured on the crystal surface with the DL after their cutting are characterized by widening of the rocking curve $\beta$ and $\beta^{\prime}$, the increase of the $R_{B}$, as well by fragmentation caused by the presence of turned crystallites in the cracked layer.

Presented in Fig. 2 is the character of the shape of DRC for the reflection $\langle 30 \overline{3} 0\rangle$ in the Laue geometry $\left(R_{i}\right)$ for $0.4 \mathrm{~mm}$ thick sample with the DL on the surface $\langle 11 \overline{2} 0\rangle$. The DRC has the fragments I, II, III of macrocrystallites formed in the cracked layer. The diameter of the fragments is 700-730 $\mu \mathrm{m}$, the angle between the frag- 


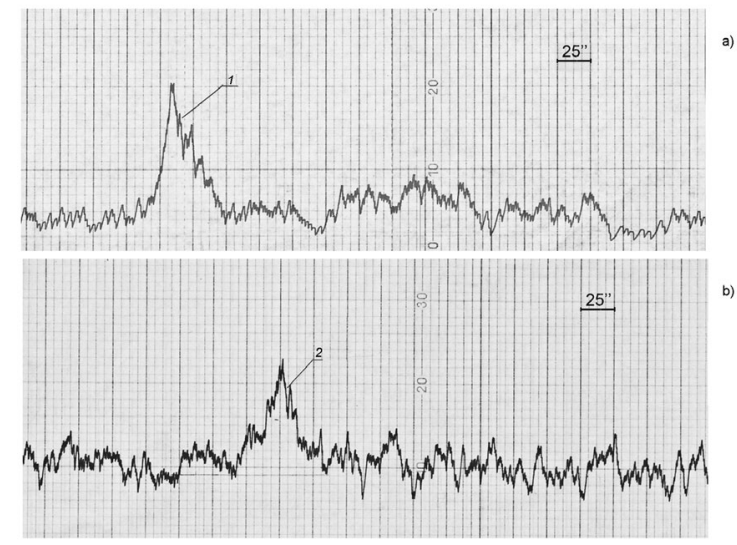

Fig. 3. DRC recorded using TCD in the reflect Laue geometry (1) and in the Laue geometry transmission (2) for the reflection $\langle 30 \overline{3} 0\rangle$. The thickness of the sample is $0.7 \mathrm{~mm}$.

ments I-III $\Delta \Theta_{\max }$ is $\sim 154 \mathrm{sec}$, the angle between the fragments I-II $\Delta \Theta_{\max }$ is $\sim 92$ sec. As seen from Fig. 2, each DRC fragment is split into a great number of smaller fragments. This is due to the presence of smaller microcrystallites with smaller angles between them. The character of the distribution of the microcrystallite sizes in the DL is shown in Fig. 4b. Distinctions in this distribution (Fig. 4) are caused by the fact that in the asymmetric Bragg diffraction (Fig. 1) the data are obtained from the upper DL surface, whereas the survey in the Laue geometry is carried out within the whole of the DL bulk. In the case of the Bragg geometry, fragmentation of the microblocks which results in fragmentation of the DRC is mainly due to the presence of turns around $\langle 11 \overline{2} 0\rangle$. In the Laue symmetric diffraction this fragmentation is caused by the presence of turns in the direction $\langle 10 \overline{1} 0\rangle$. The maximum turn of the microfragments in the DL of the irradiated sample surface does not exceed $0.3 \mathrm{deg}$. Such a turn is caused not by the neighboring microfragments, but by the crystallites with the maximum deviation $\Theta_{i}$ from the calculated value $\Theta_{B}$, thereat $\Theta_{i}<\Theta_{B}$ and $\Theta_{i}^{\prime}>\Theta_{B}$. The values $\Delta \Theta_{\max }=\Theta_{i}+\Theta^{\prime}{ }_{I}$ are presented in Table. The averaged parameter of the turn of the crystallites in the $\mathrm{DL}$ is characterized by the values $\beta, \beta_{i}^{\prime}, \sigma$ (Table). The presence of the DL on the sample with a thickness of $400 \mu \mathrm{m}$ did not allow to record the DRC for the anomalously transmitted X-ray $T_{i}$, i.e. in the investigated sample the Bormann effect was absent. At the same time, for the sample
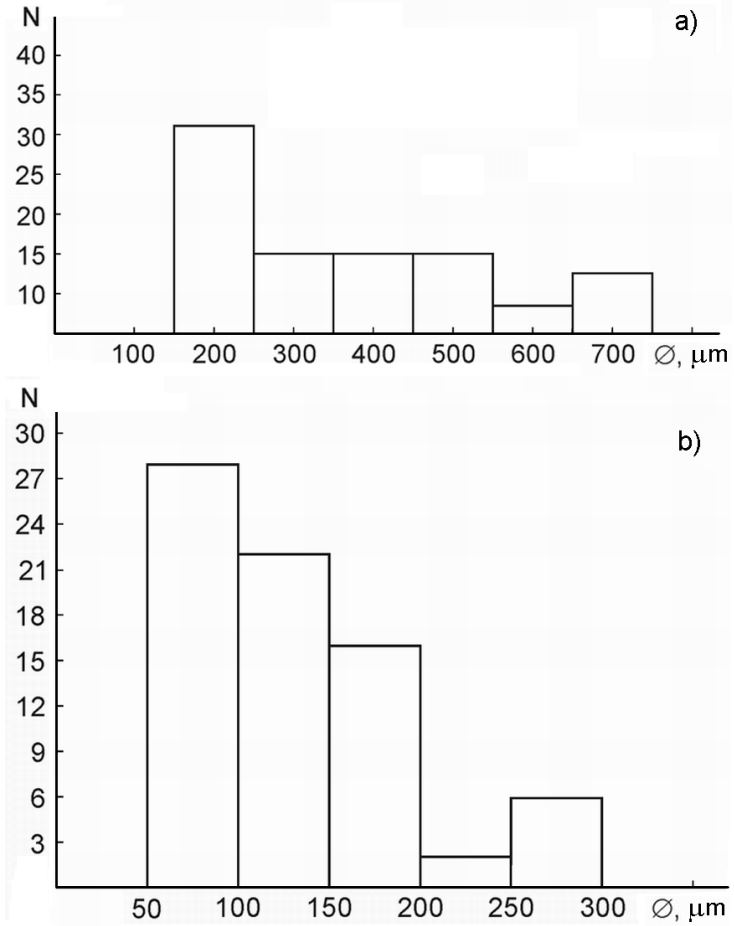

Fig. 4. Character of distribution of the sizes of crystallite fragments in the surface-adjacent damaged layer after cutting of the crystals using diamond disk. The calculations are made for DRC: a - shown in Fig. 1; b recorded in the Laue geometry, the reflection $\langle 30 \overline{3} 0\rangle$, the sample thickness is $400 \mu \mathrm{m}$.

with a thickness of $700 \mu \mathrm{m}$ and the DL on the surface $\langle 11 \overline{2} 0\rangle$ DRC have been registered both for the reflected $\left(R_{i}\right)$ and for anomalously transmitted X-rays $\left(T_{i}\right)$ with fragmentation clearly seen for both $R_{i}$, and $T_{i}$ reflections (Fig. 3). For these reflections there is established DRC widening up to $\beta=17.5^{\prime \prime}$ caused by the presence of turns of the crystallites in the cracked layer (Fig. 3).

The presence of the Bormann effect in the crystal bulk and in microfragments of the crystallites formed due to mechanical treatment testifies that there is no essential rise of dislocation density in the DL. The same conclusion was also made in [17]. Using the method of X-ray topography at indentation of the surface of sapphire crystal by means of diamond indenter, the authors observed only diffraction contrast from dislocations at the top of cracks, but not in the crystal bulk.

\section{Conclusions}

The use of the methods of precision three-crystal X-ray diffractometry in symmetric, asymmetric Bragg and Laue diffrac- 
tion geometry makes it possible to obtain qualitative and quantitative characteristics of the DL in surface-adjacent layers of sapphire crystals which appear due to mechanical and chemical-mechanical treatment. The presence of cracked layer formed after mechanical treatment leads to fragmentation of the DRC. This allows to determine not only the structure-sensitive parameters such as $\beta, \beta_{i}^{\prime}, R_{B}$, but also to calculate the meansquare disorientation between the fragments $\sigma$, the maximum angle between the crystallites $\Delta \Theta_{\max }$, as well as to establish the character of the distribution of the crystallite sizes on the surface of the investigated sample.

The presence of the fragments with small (up to $0.3^{\circ}$ ) angles of turns formed in the DL of sapphire crystals due to mechanical treatment testifies that even at cutting of the crystals by means of diamond disk using lubricating and cooling liquid the mechanism of DL formation comprises not only brittle fracture, but also plastic deformation.

\section{References}

1. V.V.Rogov, V.N.Tkach, N.D.Rublev et al., J. Superhard Mater., No.3, 67 (2008).

2. D.V.Lotsko, Yu.V.Milman, N.M.Torchun, Poverkhnost.Fizika, Khimiya, Mekhanika, No.8, 136 (1983).

3. E.Dobrovinskaya, L.Litvinov, V.Pishchik, Sapphire in Science and Engineering, Institute for Single Crystals, Kharkov (2007) [in Russian].

4. O.I.Bochkin, V.A.Bruk, S.N.NikiforovaDenisova, Mechanical Processing of Semiconductor Materials, Vysshaya Shkola, Moscow (1983) [in Russian].
5. V.P.Alekhin, Physics Of Strength And Plasticity of the Surface Layers of Materials, Nauka, Moscow (1983) [in Russian].

6. V.I.Karaban, V.V.Rogov, P.Koy et al., Processing of Semiconductor Materials, ed. by N.V.Novikova, V.Bertoldi, Naukova Dumka, Kiev (1982) [in Russian].

7. V.E.Panin, V.E.Egorushkin, Fiz. Metal. i Metallography, 110, 464 (2010).

8. A.M.Afanasiev, P.A.Aleksandrov, R.M.Imamov, Diagnostic X-ray Structure in the Study of Surface Layers of Single Crystals, Nauka, Moscow (1986) [in Russian].

9. A.Ya.Danko, V.F.Tkachenko, G.T.Adonkin et al., Poverkhnost.Rentgenouskie, Sinkhrotronnye $i$ Neitronnye Issledovaniya, No.5, 75 (1992).

10. V.M.Puzikov, A.Ya.Danko, G.T.Adonkin et al., Semiconductor Phys., Quantum Electron. Optoelectron., 3, 185 (2000).

11. V.F.Tkachenko, A.Ya.Danko, V.M.Puzikov et al., Functional Materials, 14, 321 (2007).

12. V.F.Tkachenko, O.A.Lukienko, A.Ys.Danko, V.M.Puzikov, Poverkhnost.Rentgenovskie, Sinkhrotronnye $i$ Neitronnye Issledovaniya, No.5, 58 (2013).

13. V.F.Tkachenko, O.A.Lukienko, A.T.Budnikov et al., Functional materials, 18, 171 (2011).

14. V.F.Tkachenko, M.A.Rom, A.A.Babichenko, V.I.Kuznetsov, Pribory i Tekhnika Eksperimenta, 2, 277 (1992).

15. A.Ya.Danko, V.M.Puzikov, V.P.Seminozhenko, N.S.Sidelnikova, Tekhnologicheskie Osnovy Vyrashchivaniya Leikosapfira $\mathrm{v}$ Vosstanovitelnykh Usloviyakh, ISMA NASU, Kharkov (2009) [in Russian].

16. V.F.Tkachenko, O.A.Lukienko, A.T.Budnikov et al., Functional Materials, 18, 481 (2011).

17. B.J.Hockey, J. Amer. Cer. Soc., 54, 223 (1971). 